\title{
MANAGEMENT OF SPRUCE - BALSAM STANDS TOWARDS NATURAL REGENERATION ${ }^{1}$ BY GERHARD H. EICHEL ${ }^{2}$
}

Gerhard H. Eichel was born in 1926 in Berlin. He studied at the Universities of Berlin, Göttingen, and Freiburg (Germany), and in 1950 graduated at the latter in forestry and forest engineering. By invitation of the Canadian government he decided to settle in British Columbia and joined the B.C. Forest Service in May, 1952, for three years' work classifying and sampling forests over most of the province. In July, 1955, he took the position of Resident Forester with Church Sawmill Limited, Willow River, B.C.

\section{$A B S T R A C T$}

The increased utilization of northern spruce-balsam stands has left behind very unsatisfactory pictures of regeneration after conventional cutting methods. Only in exceptional cases the desired species have regenerated without any additional organized help from man, thus pointing to the possibility of introduction or improvement of silvicultural systems.

The Cariboo section is endeavoring to establish a Forest Practice Code for this area to be adopted generally, and particularly by operators concerned with perpetual yield management.

One of my professors in silviculture used to introduce the subject with the remark: "We need a silvicultural recipe that we can apply when certain conditions are present." But he also warned constantly against generalization and emphasized the individuality of forest stands, to an extent indeed to make realization of such "recipes" dubious. Therefore, I cannot present such recipes but rather a few suggestions which eventually might result in their establishment when and if experience and experiments have proved successful.

I believe that natural regeneration always should be preferred to planting and seeding because it will provide for seeds of an established provenance. As long as seeding and planting are not restricted to certified sources of recognized provenance, local seed sources will have a clear advantage, especially in view of the unfeasibility of machine planting over most areas and the lack of hand planters in general. Nevertheless, a certain amount of planting stock should be at hand to fill in gaps where nature has failed to restock satisfactorily.

Preservation of natural conditions and adherence to the laws of nature in any treatment of the forest have proved to be the best safeguard against natural and economic disaster. That does not exclude the possibility of growing exotics in places where local growth conditions are very similar to the area of distribution of the species in question, and where this particular species promises certain advantages over indigenous species.

Before we decide to restock with the help of natural regeneration we should first investigate the species and products required, and second, whether or not local conditions will allow realization of our desire to the best advantage.

\footnotetext{
${ }^{1}$ Paper presented at the April, 1956, Cariboo Section Meeting. Accepted for publication August 19, 1956.

${ }^{2}$ Resident Forester (B.C.R.F.), Church Sawmill Limited, Willow River, British Columbia.
} 
In other words, we should strive to maintain the most suitable species ecologically in order to preserve soil proficiency. I do not believe that we should try to grow spruce in pure stands all over the country only because spruce is currently marketable. The results of this kind of monoculture can be observed in central Europe where forestry and industry still suffer from management of this kind undertaken a century or more ago. Versatility in products as well as in species has proved to be good insurance against financial disaster.

In any case, there always will be birch and aspen on clear-logged or burned areas, and balsam and alder in the understorey. All we can try to do is to prevent them from taking over the ground completely. Actually, regenerative conditions for spruce are good; it is only that often they seem to be slightly better for the undesired species. Spruce prefers bare mineral soil, or at least only a thin organic layer, to germinate, and there it will germinate well, even under cover. The trick is to give spruce a good start and preserve its advance before the other species and weeds smother the precious little seedlings.

With the exception of balsam fir, all other competitors are less tolerant than spruce. All that is needed to keep them down is to provide for a certain amount of shade. In many cases this will also cause balsam to grow less vigorously than spruce, at least at the terminal leader.

The only other way I can think of to keep reproduction of balsam behind spruce is the extermination of the seed source. Of course, that calls for costly prelogging of all mature and overmature balsam over a large area without immediate return, not to speak of profit, unless balsam finds its way into the sawtimber or pulp market. The main problem remains: how to get rid of balsam in our mature and overmature stands. The advantage of prelogging balsam fir in this way would be an enormous release of spruce growth and, if the logs are taken out, spruce regeneration on skid trails and wherever the raw humus layer has been pulled off. Seed productivity also has been observed to increase when the crown canopy is opened up, and raw humus will be decomposed faster by the increased amount of sunshine and warmth reaching the ground. Mechanical scarification could be added, but bears in itself the danger of crop trees being damaged and, therefore, should better be restricted to stands to be logged in the immediate future or to areas logged in winter.

Two or three decades after prelogging of balsam fir a good show of pure spruce will result from this seemingly unprofitable operation-if the operator is still around to reap these profits. I believe this will be one of the most successful methods to regenerate spruce and avoid balsam competition at the same time. Of course, wind and snow breakage may prevent this method from being applied everywhere, but prelogging could possibly be carried out in two or three stages several years apart to increase windfirmness among the residuals. I think most of the present prevailing wind throw could be avoided by treating stands more naturally. We cannot expect natural regeneration by treating a stand as unnaturally as, for example, cutting down with one blow all trees from a certain and rather large diameter up. It would be far better to cut everything down, clear the ground, and run a planting machine back and forth. 
One of the most important rules of silviculture is taught in European schools in the first lesson on the subject: Treat often, and gently-meaning steadily, and early. For the latter part we have come too late, with a few exceptions. The two others could and should be observed, however, and very much to the advantage of any timber stand. Often stands are dense, with trees almost leaning against each other; these should be opened up slowly. I am convinced that, just as in Europe, spruce can be treated in a way to make it windfirm, even if first we have to use balsam to keep it in place. Treatment to increase windfirmness probably is more promising than clear cutting, either over large or small areas, but it does require a rather dense network of access and haul roads combined with a strict organization.

Large areas consist of understocked, overmature stands, mostly in patches between Sitka alder brush. Often these stands are very open and invite the use of a tractor with brushing hooks to clear out the alder and prepare a suitable seed bed. Regeneration of spruce in this way could best be timed for a year with a good seed crop. At the same time the timber patches could be prelogged; helping to provide the desired seed bed. After the last cut, the ground would be left covered by advance spruce regeneration.

Experiments in Alaska, using chemicals to kill Sitka alder, were quite successful and not too costly, but general application might fail here because of our extensive areas covered by this weed, coupled with a lack of access and a shortage of manpower.

Clearcutting on small spots, over an area not too large to inhibit road construction, promises to become a feasible method, at least as a temporary measure, where there is little danger of wind throw. In other areas it may be hazardous; every opening into the crown canopy, even though it may be small, presents a projection into the wind.

Strip cutting has been tried with and without success, and is still being tried repeatedly because of easy accessibility and distinct organization. But, if the wind should get into some of these clearcut strips between timber left standing, it will accelerate and trees will be flying right and left. A system of staggered strips of limited length, resulting in sort of a chessboard or zigzag pattern, appears to be more successful.

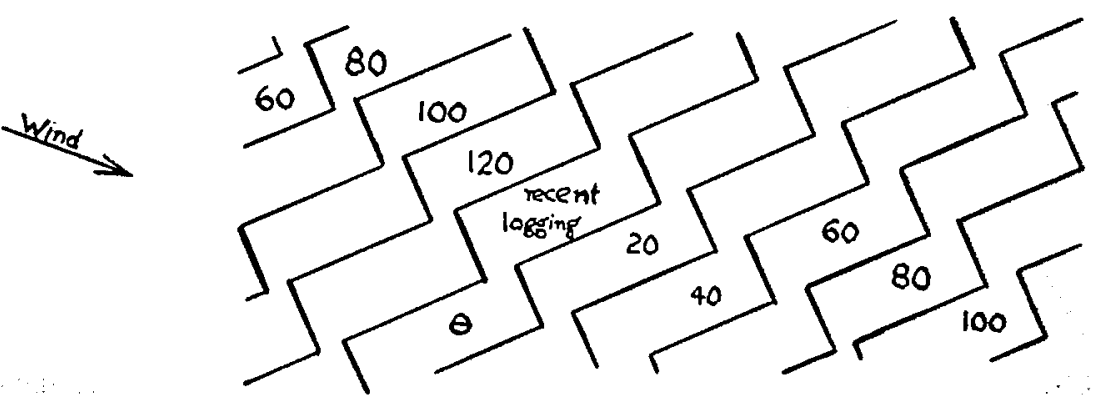

FIGURE 1: Ideal cutting pattern of staggered strip system, designed to move into the main wind direction. Figures denote age classes. 
But all these methods are rather artificial and always create abrupt disturbances of the delicately balanced stand structure. Another possible disadvantage of clearcutting in the wetbelt area might be the disturbance of the equilibrium of the water budget. Besides the danger of mechanical erosion caused by the increased speed of runoff on cleared land, it also could easily happen in the more level parts of the country that after clearcutting, the formerly only moderately moist ground becomes extremely wet and even swampy with the unwelcome vegetation types such as horsetail, fern, willows, etc. In Europe we call spruce the "drunkard among the trees" and often plant it for the sole purpose of draining swamps and bogs.

There remains one method left to be mentioned which has been applied quite successfully over some 50 or 60 years under conditions very similar to prevailing ones here and with practically the same species, spruce and balsam. I speak of Eberhard's shelter wedge system in the northeastern Black Forest. Slow opening of the stand and clearcutting over small multiple areas are combined to a form of management successful to both the forest and its user.

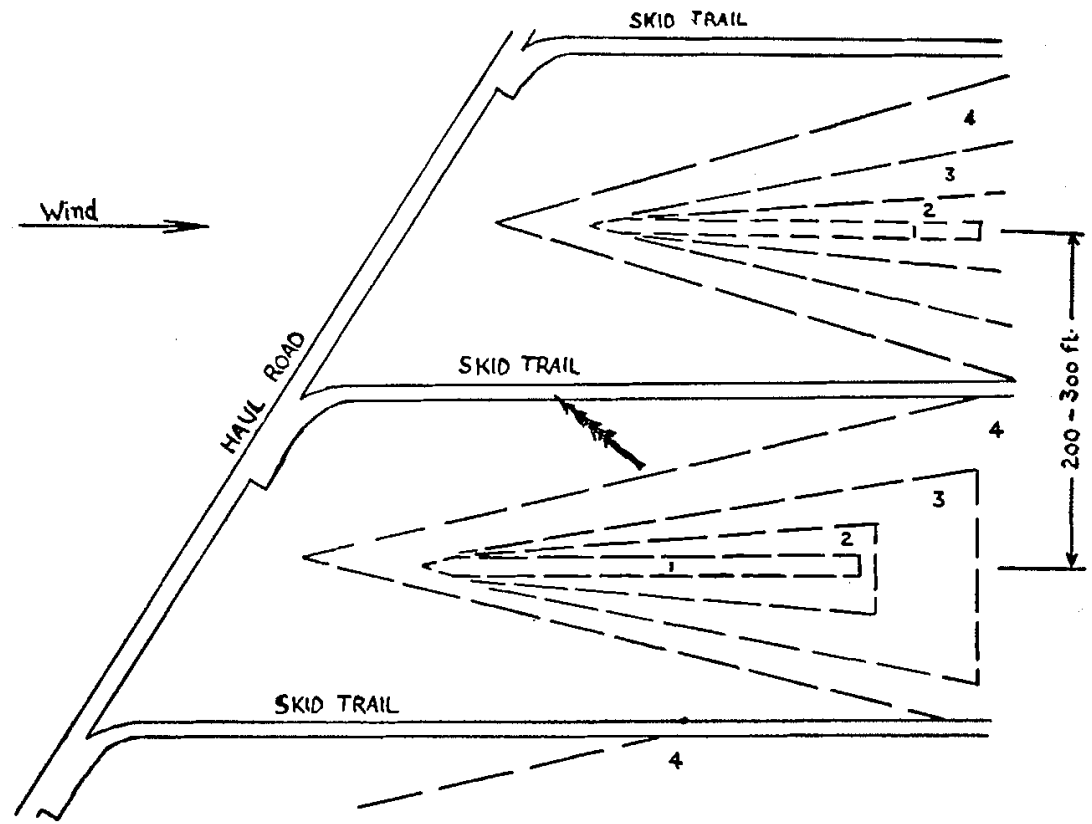

FIGURE 2: Ideal pattern and sequence of cuttings during four periods in Eberhard's shelter wedge system. In rolling or mountainous terrain wedges should always point downhill for ease of skidding; a special key for cuttings has been devised to conform method to these conditions. 
The stand first is opened up equally over the whole area to increase windfirmness; up to twenty and more per cent of the total volume is extracted in one or two initial cuttings, leaving behind what is known as the "skeleton" of the stand. After these structural trees have become windfirm enough and regeneration starts to show up underneath, long narrow strips (about 20 feet wide) are clearcut along "skidding divides" between two skid trails and from 200 to 300 feet apart, pointing into the direction of the strongest prevailing wind. Trees are felled herring bone fashion towards the skid trails and taken out whole length through the remaining stand in order to scarify the ground for seed bed.

The cutting period is determined by the rate of regeneration, but generally cutting will not exceed 200 cubic feet per acre per year; more often it will be less. This calls, of course, for a mobile loading unit in place of the concentrated landing, since at each operation there will be only a small amount of logs at the end of each skid trail. On the other hand, with a network of roads and trails once established and maintained, operation can be spread over the area without disturbing the stand structure, allowing operations to be conducted on a very flexible schedule.

\section{REFERENCES}

1. Alaska Forest Research Center. 1954. Annual report.

2. BARNES, G. H. 1957. The development of unevenaged stands of Engelmann spruce and probable development of residual stands after logging.

3. DENGLER, A. 1930. Waldbau auf Oekologischer Grundlage (Silviculture on ecological basis).

4. FRASER, A. R. and J. L. ALEXANDER. 1949. The development of the spruce-balsam type in the Aleza Lake Experimental Forest.

5. POGUE, H. M. 1946. Regeneration and growth of white spruce after logging. 